\title{
OESTROUS RESPONSE OF OVARIECTOMIZED BEEF HEIFERS TO OESTRADIOL BENZOATE AND HUMAN CHORIONIC GONADOTROPHIN
}

\author{
D. E. RAY* \\ Animal Science Department, South Dakota State University, \\ Brookings, South Dakota, U.S.A.
}

(Received 14th Fanuary 1965)

Summary. A total of sixty ovariectomized beef heifers were involved in two trials to study the effects of oestradiol benzoate (ODB) and human chorionic gonadotrophin (HCG) on induced oestrous behaviour. Both hormones were administered in single injections, ODB subcutaneously in sesame oil and HCG intramuscularly in physiological saline. Dosages evaluated were: ODB-0.2, $0 \cdot 3,0 \cdot 4,0.5$ or $0.6 \mathrm{mg}$; HCG $-0,2000$ or 5000 i.u. Animals were observed twice daily and scored for oestrous behaviour on a scale from 0 to 5 .

The minimal dose of oDB sufficient to induce 'standing' oestrus was $0.3 \mathrm{mg}$. The proportion of animals in heat, length of oestrus and total score tended to increase with increasing levels of ODB. HCG administration (concurrent with ODB) significantly delayed the onset of oestrus following injection in one trial, with the same tendency (non-significant) observed in the other trial.

Inexplicable oestrous behaviour was observed in several heifers after ovariectomy and hormone treatment.

\section{INTRODUCTION}

The induction of oestrus in the ovariectomized bovine has received limited attention. Asdell, de Alba \& Roberts (1945) reported that the average level of oestradiol benzoate (ODB) necessary to induce oestrus in the ovariectomized heifer was $0.1 \mathrm{mg}$ daily for 3 days. Reece (1951) reported that oestrogens administered subcutaneously were more effective in inducing oestrus than when administered orally. Synergistic and antagonistic hormone interactions on oestrous response have been studied by Melampy, Emmerson, Rakes, Hanka \& Eness (1957) and Melampy \& Rakes (1958).

Recent work has indicated that human chorionic gonadotrophin (HCG) will suppress oestrus in intact heifers (Wiltbank, Rothlisberger \& Zimmerman, 1961). These workers conclude that oestrous suppression is due to functional maintenance of the corpus luteum during HCG administration. This conclusion has been strengthened by the studies of Simmons \& Hansel (1964). However, preliminary studies at this station (unpublished) raised the question whether

* Present address: Department of Animal Science, University of Arizona, Tucson, Arizona. 
HCG could exert some effect on extragonadal site(s). The possibility that pituitary hormones may exert a direct effect on the hypothalamus was discussed by Szentagothai, Flerko, Mess \& Halasz (1962) and Sawyer \& Kawakami (1961). Szontagh \& Uhlarik (1964) recently presented evidence suggesting that pregnant mare's serum gonadotrophin exerts a direct inhibitory effect on the hypothalamic control of pituitary luteinizing hormone in the rat. The hypothalamus has also been implicated as a primary target for oestrogeninduced sexual behaviour in ovariectomized cats (Harris \& Michael, 1964). It thus appears that the effects of both oestrogenic and gonadotrophic hormones may be partially mediated by the hypothalamus.

The experiments discussed herein were conducted to evaluate the actions and interactions of ODB and HCG on various parameters of oestrous activity in the spayed beef heifer.

\section{MATERIALS AND METHODS}

Two trials were conducted during the winters of 1962-63 and 1963-64. Trial 1 involved twenty-four and Trial 2 thirty-six ovariectomized Hereford heifers approximately 18 to 24 months of age. Ovariectomy was performed through a supra-vaginal incision under epidural anaesthesia. At least 30 days elapsed between ovariectomy and hormone injections. During the entire experimental period all animals were checked twice daily (a.m. and p.m.) for oestrus with vasectomized bulls. Completeness of ovariectomy was assessed at slaughter.

In the first trial (1962-63) six heifers were assigned to each of four treatment combinations $(0.2$ or $0.6 \mathrm{mg}$ ODB +0 or 2000 i.u. HCG). Oestradiol benzoate was administered in $5 \mathrm{ml}$ sesame oil as a single subcutaneous injection in the neck region. HCG was administered as a single intramuscular injection in $2 \mathrm{ml}$ of physiological saline in the rump. Both hormones were administered at the same time to each heifer. Four animals (one on each treatment combination) were treated on a given date with 2 to 3 days elapsing before the next group was injected. Injection dates were staggered to ensure that bull libido would not be a limiting factor in detection of oestrus during the experimental period.

Six treatment combinations were utilized in the second trial (1963-64) with six animals per treatment. Three levels of oDB were studied $(0 \cdot 3,0.4$ or $0.5 \mathrm{mg}$ ) in combination with two levels of HGG ( 0 or 5000 i.u.). Hormone carriers and routes of administration were identical to Trial 1 except that HGG was administered in $5 \mathrm{ml}$ physiological saline and the ' 0 ' level of HCG received physiological saline only. One animal on each treatment combination was injected on a given date with at least 3 days elapsing between injection groups.

A scoring system was devised to quantify oestrous behaviour following injection (Table 1). Each animal was scored twice daily (a.m. and p.m.) on the day of injection and for seven subsequent days. At each observation each animal received the highest score consistent with the symptoms exhibited.

Data were statistically evaluated as a $2 \times 2$ (Trial 1) or $2 \times 3$ (Trial 2) factorial arrangement, using analysis of variance techniques or Chi-square depending on the nature of the data. The method of unweighted means was 
utilized for data involving unequal subclass numbers (Snedecor, 1956). Only the scores obtained in the first eight observations after treatment were utilized in the analyses, unless otherwise noted.

\section{TABLE 1}

SCORING SYSTEM FOR OESTROUS BEHAVIOUR

\begin{tabular}{|c|c|}
\hline Score & Description \\
\hline 0 & No symptoms of oestrus \\
\hline 1 & Animal restless and/or mucous discharge from vagina \\
\hline 2 & $\begin{array}{l}\text { Homosexual behaviour-animal attempts to mount (or mounts) } \\
\text { other heifers not in heat }\end{array}$ \\
\hline 3 & $\begin{array}{l}\text { Others (male or female) show interest in animal, but she will not } \\
\text { stand to be mounted }\end{array}$ \\
\hline 4 & Stands to be mounted by other heifers \\
\hline 5 & Male acceptance-stands to be mounted by bull(s) \\
\hline
\end{tabular}

TABLE 2

RESULTS OF TRIAL 1

\begin{tabular}{|c|c|c|c|c|c|}
\hline & \multicolumn{5}{|c|}{ Treatment $\mathrm{ODB}, m g ;$ HCG, i.u. $\dagger$} \\
\hline & $0 \cdot 2 ; 0$ & $\begin{array}{l}0 \cdot 2 ; \\
2000\end{array}$ & $0 \cdot 6 ; 0$ & $\begin{array}{l}0 \cdot 6 \\
2000\end{array}$ & $\begin{array}{l}\text { Significant } \\
\text { differences }\end{array}$ \\
\hline $\begin{array}{l}\text { No. animals } \\
\text { No. in heat } \\
\text { Average No. observations in heat } \\
\text { Average No. observations, injection to oestrus } \\
\text { Average total score, heifers in oestrus } \\
\text { Average total score, all heifers } \\
\text { No. animals with some response } \\
\text { Average No. observations with response, all } \\
\text { heifers } \\
\text { No. with response after eight observations } \\
\text { post-injection }\end{array}$ & $\begin{array}{l}4 § \\
0 \\
- \\
\overline{-} \\
0 \cdot 5 \\
1 \\
0 \cdot 2 \\
1\end{array}$ & $\begin{array}{l}6 \\
0 \\
- \\
\overline{-} \\
0 \cdot 0 \\
0 \\
0 \cdot 0 \\
0\end{array}$ & $\begin{array}{l}6 \\
5 \\
2 \cdot 2 \\
4 \cdot 2 \\
11 \cdot 8 \\
10 \cdot 8 \\
6 \\
2 \cdot 8 \\
3\end{array}$ & $\begin{array}{l}6 \\
5 \\
1 \cdot 2 \\
5 \cdot 0 \\
9 \cdot 4 \\
8 \cdot 3 \\
6 \\
2 \cdot 7 \\
4\end{array}$ & $\begin{array}{l}\mathrm{E}^{* *} \\
\mathrm{E}^{* *} \\
\mathrm{E}^{* *} \\
\mathrm{E}^{* *} \\
\mathrm{E}^{* *} \\
\mathrm{E}^{*}\end{array}$ \\
\hline
\end{tabular}

$\lceil$ ODB $=$ oestradiol benzoate, HCG $=$ human chorionic gonadotrophin.

$\$ \mathrm{E}$ indicates a significant difference between oestradiol benzoate levels, $* P<0.05, * * P<0.01$.

$\$$ Two heifers omitted from this treatment due to ovarian remnants found at slaughter.

It The unit of time utilized in this study is an 'observation' with two observations (a.m. and p.m.) per day.

\section{RESULTS}

Table 2 summarizes the results obtained in the first trial. A single subcutaneous injection of $0.2 \mathrm{mg}$ ODB was not adequate to induce oestrus in any of twelve heifers receiving this dosage, although $0.6 \mathrm{mg}$ resulted in ten of twelve heifers exhibiting standing heat. Only one animal on the lower oDs level exhibited any response during the first eight observations (score of 2 for one observation). At slaughter two heifers on the low levels of both hormones were found to have 
remnants of ovarian tissue. They were excluded from further consideration in the analyses, although their behaviour was consistent with other animals on the same treatment combination.

No statistically significant effects of HCG were noted. However, there was a tendency for animals receiving 2000 i.u. HCG to have a prolonged interval from injection to standing heat (score of 4 or 5) and for the length of oestrus to be shorter than heifers not receiving HGG.

Although none of the animals exhibited standing heat between the seventh observation post-injection and the end of the 8-day test period, there was an indication of prolonged oestrogen action at the higher dosage. Seven of twelve heifers on the $0.6 \mathrm{mg}$ level exhibited some oestrous activity after eight observations post-injection, whereas only one of ten on the $0.2 \mathrm{mg}$ level received a score higher than zero during the same time interval.

TABLE 3

RESULTS OF TRIAL 2

\begin{tabular}{|c|c|c|c|c|c|c|c|}
\hline & \multicolumn{7}{|c|}{ Treatment ODB, $m g ;$ HCG, i.u. $\dagger$} \\
\hline & $\begin{array}{c}0.3 \\
0\end{array}$ & $\begin{array}{c}0 \cdot 3 ; \\
5000\end{array}$ & $\begin{array}{c}0.4 ; \\
0\end{array}$ & $\begin{array}{l}0.4 \\
5000\end{array}$ & $\stackrel{0.5}{0}$ & $\begin{array}{l}0 \cdot 5 \\
5000\end{array}$ & $\begin{array}{l}\text { Significant } \\
\text { differences }\end{array}$ \\
\hline $\begin{array}{l}\text { No. animals } \\
\text { No. in heat } \\
\text { Average No. observations in heat } \$ \\
\text { Average No. observations, injection to } \\
\text { oestrus } \\
\text { Average total score, heifers in oestrus } \\
\text { Average total score, all animals } \\
\text { No. animals with some response } \\
\text { Average No. observations with response, } \\
\text { all heifers } \\
\text { No. with response after eight observations } \\
\text { post-injection }\end{array}$ & $\begin{array}{l}6 \\
3 \\
1 \cdot 7 \\
3 \cdot 3 \\
10 \cdot 3 \\
6 \cdot 0 \\
5 \\
1 \cdot 7 \\
2\end{array}$ & $\begin{array}{c}6 \\
3 \\
1 \cdot 3 \\
5 \cdot 0 \\
10 \cdot 7 \\
5 \cdot 8 \\
4 \\
1 \cdot 8 \\
0\end{array}$ & $\begin{array}{l}3 \cdot 8 \\
9 \cdot 2 \\
9 \cdot 2 \\
6 \\
2 \cdot 7\end{array}$ & $\begin{array}{c}4 \cdot 0 \\
12 \cdot 2 \\
12 \cdot 2 \\
6 \\
3 \cdot 2\end{array}$ & $\begin{array}{l}6 \\
6 \\
2 \cdot 3 \\
\\
3 \cdot 2 \\
12 \cdot 3 \\
12 \cdot 3 \\
6 \\
3 \cdot 2\end{array}$ & $\begin{array}{c}4.2 \\
10 \cdot 5 \\
10 \cdot 5 \\
6 \\
3 \cdot 0\end{array}$ & $\begin{array}{l}\mathrm{E}^{*} \\
\mathrm{E}^{*} \\
\mathrm{E}^{*}\end{array}$ \\
\hline
\end{tabular}

$\dagger$ ODB $=$ oestradiol benzoate, HCG $=$ human chorionic gonadotrophin.

$\mp \mathrm{E}$ indicates a significant difference between oestradiol benzoate levels, $\mathrm{G}$ between human chorionic gonadotrophin levels; $* P<0.05, * * P<0.01$.

$\$$ The unit of time utilized in this study is an 'observation', with two observations (a.m. and p.m.) each day.

Assuming that HCG was only slightly antagonistic to the oestrus inducing action of ODB, dosages of ODB were reduced in an attempt to induce a submaximal response in Trial 2. Also, HCG dose was increased to 5000 i.u. The results of this trial are presented in Table 3.

Significant differences with respect to ODB levels were observed for the number of heifers in standing heat, the number of animals with some response, the average number of observations of response and the average total score of all heifers during the first eight observations. However, the length of oestrus (number of observations in heat) was not significantly affected by either variable.

Interval from injection to oestrus was significantly increased by HCG $(3.5$ versus $4 \cdot 3$ observations, approaches $1 \%$ level of significance). This is consistent 
with the results obtained in the first trial, although this effect was not statistically significant in Trial 1.

As in Trial I, there was an indication of prolonged oestrogen action at the higher oDB levels (number with response after eight observations) although this effect was not statistically significant. There was also a tendency noted for 'split' oestrus at the $0.5 \mathrm{mg}$ ODB level.

\section{DISCUSSION}

The minimal level of ODB in these studies necessary to induce sexual receptivity in the ovariectomized beef heifer $(0.3 \mathrm{mg})$ is in general agreement with the data of Melampy et al. (1957) and Melampy \& Rakes (1958). Limited evidence (Asdell et al., 1945; Reece, 1951) indicates that the total dose is the limiting factor and not the duration or number of injections. For example, Asdell et al. (1945) found that three daily injections of $0.1 \mathrm{mg}$ ODB would induce heat in spayed heifers. The same general relationship was observed in the spayed ewe by Brander \& Robinson (1962).

Melampy et al. (1957) reported that progesterone, testosterone propionate and desoxycorticosterone acetate were synergistic with oestradiol benzoate in inducing oestrus in spayed cows. Each of these hormones would induce oestrus in the 'oestrogen-primed' female (dose of ODB insufficient to produce standing heat).

The observation that 'progesterone priming' greatly increases the sensitivity of the spayed ewe to oestrogens (Robinson, 1959) is of interest. Robinson \& Brander (1962) reported an $\mathrm{ED}_{50}$ value for behavioural oestrus of $11 \mu \mathrm{g}$ of ODB intramuscularly in the spayed, progesterone primed ewe. Although comparable data are not available in the cow, the work of Melampy et al. (1957) suggests that a similar relationship may exist.

The intervals from injection to oestrus and the duration of oestrus were somewhat longer in the present studies than those reported by Melampy et al. (1957). In their study, observations for oestrus were made at 3-hr intervals, whereas only twice daily observations were made in the present studies, resulting in less precise estimates of these parameters as compared to their results. The fact that both of the present studies were conducted during the winter may have also contributed to these discrepancies.

An indication of an antagonism between ODB and HCG was observed in these studies. Average interval from injection to oestrus was significantly increased by HCG administration in the second trial, and the same trend was also noted in Trial 1. However, other parameters of oestrous response were not significantly affected by HCG.

If HGG does interfere with the response of the ovariectomized bovine to oestrogen action, two possible mechanisms to explain this inhibitory effect would be (1) by decreasing the sensitivity of target organ(s) to oestrogen action or by (2) chemical binding of oestrogen (to HGG?) in such a manner as to reduce its biological activity.

Evidence has been presented (Harris \& Michael, 1964) indicating that the hypothalamus is the target organ for oestrogen-induced sexual receptivity in 
the cat. It has also been suggested that pituitary hormones may exert a direct effect on the hypothalamus (Sawyer \& Kawakami, 1961; Szentagothai et al., 1962; Szontagh \& Uhlarik, 1964). Therefore, there is circumstantial evidence to form a basis for the first mechanism suggested.

Certain steroids can be bound to blood proteins and this binding action may be a significant factor in the transport and release of the steroid to reacting tissues (Westphal, 1961). It is therefore conceivable that a gonadotrophic hormone, which is a protein ( $\mathrm{HCG}$ ), could become involved in the second mechanism suggested above.

These possible modes of action are speculative, and the basic assumption of an interaction between HCG and ODB needs to be further substantiated. Nevertheless, these data do suggest that such a mechanism may exist.

An interesting observation from Trial 1 was the aberrant oestrous behaviour noted after the oestrogen-induced heat period and after ovariectomy with no subsequent treatment. Two heifers receiving $0.6 \mathrm{mg}$ ODB were observed in standing heat 24 and 43 days after injection. Three ovariectomized animals, which were not included in this trial, were also observed in heat 15 to 31 days after ovariectomy. One of the latter heifers had two additional heat periods at intervals of 13 and 21 days. None of the above heifers had observable remnants of ovarian tissue when slaughtered. The reason for this aberrant behaviour is unknown. Wodzicka-Tomaszewska (1963) observed similar phenomena in ovariectomized ewes subsequent to oestrogen injections.

\section{ACKNOWLEDGMENTS}

Published with the approval of the Director of the South Dakota Agricultural Experiment Station as Publication No. 667 of the Journal Series. A portion of the HCG (Follutein) was supplied by Dr A. D. Rankin, The Squibb Institute, New Brunswick, New Jersey.

\section{REFERENCES}

Asdell, S. A., DE Alba, J. \& Roberts, J. S. (1945) The levels of ovarian hormones required to induce heat and other reactions in the ovariectomized cow. F. Anim. Sci. 4, 277.

Brander, W. M. \& Robinson, T. J. (1962) Effect of duration of intravenous injection on the response of the spayed ewe to oestradiol benzoate (ODB). F. Reprod. Fertil. 3, 64 .

Harris, G. W. \& Mrchael, R. P. (1964) The activation of sexual behavior by hypothalamic implants of oestrogen. F. Physiol. 171, 275.

Melampy, R. M., Emmerson, M. A., Rakes, J. M., Hanka, L. J. \& Eness, P. G. (1957) The effect of progesterone on the estrous response of estrogen-conditioned ovariectomized cows. F. Anim. Sci. 16, 967.

Melampy, R. M. \& Rakes, J. M. (1958) Induced estrus in ovariectomized cows. Iowa State College $\mathcal{F}$. Sci. 33, 85.

REEGE, R. P. (1951) A comparison of the effectiveness of estrogens in inducing estrus in dairy cattle (Abstr.). F. Dairy Sci. 34, 495.

Robinson, T. J. (1959) The estrous cycle of the ewe and doe. Reproduction in Domestic Animals, vol. 1. Eds. H. H. Cole and P. T. Cupps. Academic Press, New York.

Robinson, T. J. \& BRANDER, W. M. (1962) Comparative activities of a number of oestrogens when administered intravenously and intramuscularly in the sheep. 7. Reprod. Fertil. 3, 74.

SAwyer, G. H. \& KawaKami, M. (1961) Interactions between the central nervous system and hormones influencing ovulation. Control of Ovulation. Ed. Claude A. Villee. Pergamon Press, New York.

Simmons, K. R. \& Hansel, W. (1964) Nature of the luteotropic hormone in the bovine. F. Anim. Sci. 23, 136. 
SNedecor, G. W. (1956) Statistical Methods, 5th edn. Iowa State College Press, Ames, Iowa.

Szentagothai, J., Flerko, B., Mess, B. \& Halasz, B. (1962) Hypothalamic control of the anterior pituitary. Akademiai Kiado (Publishing House of the Hungarian Academy of Sciences), Budapest, Hungary.

Szontagh, F. E. \& UHLaRIK, S. (1964) The possibility of a direct internal feedback in the control of pituitary gonadotrophin secretion. F. Endocrin. 29, 203.

WestPHAL, U. (1961) Interactions between steroids and proteins. Mechanisms of Action of Steroid Hormones. Eds. Claude A. Villee and Lewis L. Enge]. Pergamon Press, New York.

Wiltbank, J. N., Rothlisberger, J. A. \& Zimmerman, D. R. (1961) Effect of human chorionic gonadotrophin on maintenance of the corpus luteum and embryonic survival in the cow. F. Anim. Sci. 20, 827.

WodzicKa-ToMAszEWSKA, M. (1963) Bioassay of oestrogen and recurring oestrus in ovariectomized ewes. Nature, Lond. 198, 299. 